\title{
SPATIALITY OF LOCAL GOVERNMENTS IN EUROPEAN INTERMEDIATE URBAN REGIONS: A METHODOLOGICAL APPROACH
}

\author{
Christophe Breuer, Jean-Marie Halleux \\ Department of Geography, University of Liège, Liège, Belgium \\ Manuscript received: February 3, 2016 \\ Revised version: April 15, 2016
}

\begin{abstract}
BREuER C., HAlleuX J.-M., 2016. Spatiality of local governments in European intermediate urban regions: A methodological approach. Quaestiones Geographicae 35(2), Bogucki Wydawnictwo Naukowe, Poznań, pp. 39-58, 10 figs, 4 tables.

ABSTRACT: Local authorities are central actors in the governance of European intermediate urban regions. In this paper, we propose a methodology to analyse the fragmentation of local authorities within 119 urban regions. We tested several European databases to create indicators of fragmentation and to develop a typology of fragmentation within cities. Our results show that the Eurostat Cities programme gives a consistent spatial definition of urban regions and that their fragmentation is mainly influenced by national contexts. The developed methodology is a contribution to the debate on territorial reforms and urban governance transformations.
\end{abstract}

KEY wORDS: urban governance, local authorities, governance indicators, geography of governance, European intermediate cities

Corresponding author: Christophe Breuer, Department of Geography, University of Liège, Clos Mercator 3 (B11), 4000 Liège,

Belgium; e-mail: christophe.breuer@ulg.ac.be

\section{Introduction}

Political-administrative local units are the basic level of state organisation. In Europe, these entities cover almost all national territories with the noteworthy exception of some military areas and sparsely populated regions. This framework of communes, communities, municipalities and districts represents the basic level of government and democracy of our continent. These local authorities play a decisive role in everyday life of citizens, their major competences being local infrastructures, public and social services, education, culture and heritage, urban planning, local taxation, mobility and transport, etc. The shape and competences of local administration are the legacy of local, regional and national history. They are therefore strongly embedded in territorial cultures. The competences of local governments depend on national legislation, so they vary greatly from one country to another. In federal or highly decentralised states, these competences can also vary from one region to another. However, local authorities share a common form of political autonomy and self-government for local issues. These principles of political autonomy and autonomous government are generally guaranteed by constitutional and territorial organisation laws at the state level.

Local authorities are also subject to many pressures, such as demographic changes, transformations of the global economy, budgetary, 
legislative and regulatory constraints, or technological breaks. They try to meet those challenges in an ever-changing environment by restructuring or changing their structures and modes of action. Reforms of local authorities are old and numerous, as evidenced by decentralisation processes, municipality merging, inter-municipal associations, supra-communal reforms, etc. The transformation of the role of local governments, the emergence of new actors (public, para-public and private actors) and the strengthening of less hierarchical modes of coordination are described by theories of local, territorial and urban types of governance (Bevir 2011; Le Galès 2011; Pasquier et al. 2013). These major changes have implications for the spatiality of local governments, a theme which is the central topic of this paper.

Unlike 'modern governance' proponents who see in local authorities one actor among others coordinated by networks (Rhodes 1996), we defend the thesis that public authorities receive specific resources that make them central actors in local governance. The amount of the financial resources of local authorities - responsible for $27 \%$ of public expenditures (Eurostat 2015) - is illustrative of this significant capacity. In this perspective, we consider it essential to shed light on the spatiality of local authorities in order to adequately apprehend urban governance and the related complex interactions between public actors, non-governmental actors and governmental actors at an upper level.

Transformations of the spatiality of local governments have often been analysed in terms of urban governments. Indeed, by definition, urban areas concentrate populations and are nodes of territorial interactions that bring them at the forefront of societal changes. According to Le Galès (2011), urban governments have been able to reposition themselves as key actors in local governance due to the stress relief of nation-states and because of the development of both, supra-national structures (e.g. the European Union) and infra-national ones (regions). Geographers see this evolution as a consequence of both, the territorialisation of globalisation dynamics and the rescaling of social and economic structures (Brenner 1999).

In the 1980s, research on territorial reforms and urban governance focused primarily on global cities. Such focus in this period can be explained by the emergence of world-wide networks, but also by the huge management problems faced then by the main metropolitan areas (Sharpe 1995). Afterwards, researchers focused on so-called European metropolises, i.e. cities whose demographic weight allowed them to be considered of international standing. Nowadays, we see an increasing interest in intermediate cities. At first sight, they can be defined by the conjunction of an incomplete international integration and a strong influence of their regional contexts. Intermediate cities have diverse profiles inherited from history and territorial specificity, but they usually occupy an unstable position between the international and the local. Despite their demographic importance at the scale of the continent, they have been poorly studied and are still subject to discussion on their management and future.

The research synthesised in this article is methodological and exploratory. Its first aim was to develop, test and validate a methodology to study the fragmentation of local authorities in European intermediate urban regions, despite the difficulty of data harmonisation across the continent. Our study area covered the 28 EU states as well as three associated countries (Norway, Switzerland and Iceland).

Our methodological approach developed in three stages: first, by an analysis of the available delimitations of the European urban regions, secondly by the selection of intermediate cities, and thirdly by an analysis of fragmentation indices. The fragmentation indices considered are the average population by local authority and the average area by local authority. The developed methodology led to the creation of a database allowing analyses at both, the national and the international level. We consider that this database could be useful for various purposes: to contribute to the debate on territorial reforms and urban governance transformation, to introduce further research on links between local fragmentation and the strengthening of supra-local coordination and association structures, and to develop urban benchmarking in European countries.

The rest of the article is structured as follows. In chapter 2 we clarify the notion of a European intermediate urban region. In chapter 3 we analyse the size of local governments for the whole of the study area. This analysis notably reveals strong 
disparities among European countries in terms of local government fragmentation. In chapter 4 we develop a methodology for a study of the fragmentation of local authorities in European intermediate urban regions. Some initial results on the fragmentation indices are developed in chapter 5 , and chapter 6 concludes the analysis.

\section{Intermediate cities in Europe}

\section{What do we mean by 'intermediate cities'?}

In 2013, metropolises, large cities, towns and their suburban areas were home of $72.4 \%$ of the population of the $28 \mathrm{EU}$ countries (Eurostat $2014,2015)$. This growing figure is linked to the concentration of economic activities in urban areas, especially in large cities whose productivity is significantly higher than national averages (Budde et al. 2010; Eurostat 2015). This competitive advantage of large and very large cities has been theorised by the 'new economic geography' specialists, who see in this situation a result of agglomeration economies. It has also been considered by proponents of the advantage of interconnected cities in the context of globalisation (Castel 1996; Scott 2001; Sassen 2001). Although this competitive advantage of metropolises has been nuanced by empirical studies (Turok 2007; David et al. 2013), it is still the basis of contemporary development strategies in Europe. Meanwhile, major cities remain the focal point of analysts working on societal issues (cohesion, segregation, the quality of life), environmental issues (sustainability, resilience), or innovation issues (social and technological innovations). As a consequence, metropolises continue to occupy a central place in policy agendas as well as in research agendas (e.g. Evans 2015; Parkinson 2001; European Commission 2011; Gouvernement wallon 2014; Hamza et al. 2014).

Although they often aspire to become metropolises interconnected in international interdependence systems, intermediate cities generally follow another trajectory: they often have to recompose a local economy hit by the end of Fordism, to struggle against the displacement of specialised functions and major infrastructures towards metropolises (metropolitanisation dynamics), and to provide services for their populations and firms (Saint-Julien 2003). Intermediate cities have been marginalised twice: first by economic, technological, spatial and scale transformations; and secondly by territorial strategies struggling to identify their role in European urban systems. This marginalisation probably explains the lack of research on intermediate cities (Evans 2015; Giffinger 2008) and contributes to the consolidation of this urban category as a research object per se.

Intermediate cities have rather been defined by default: neither metropolises fully integrated in continental or global networks, nor local cities solely embedded in their regional contexts (Saint-Julien 2003; Carrière 2008; Cornett 2014). Sometimes they have been described as medium or secondary cities. In fact, they are not clearly identified geographical objects; Brunet called them "unidentified real objects" (1997). Some authors have considered population thresholds for identifying city types for analytical purposes. Comparative analyses of European cities carried out in France initially adopted the threshold of 200,000 inhabitants to identify "cities that can claim to play an effective role at a continental level" (Brunet 1989; Rozenblat et al. 2003: 14). Dumont (2012) also used this threshold to describe "intermediate regional metropolises". Antier (2005) considered major cities to have between 0.2 and 1.0 million inhabitants. Turok et al. (2007) put medium-sized cities in Europe to have between 0.4 and 1.0 million inhabitants, while Giffinger et al. (2008) proposed as intermediate cities those with between 0.1 and 0.5 million inhabitants. These examples demonstrate the lack of a consensus and the difficulty - if not the impossibility - of specifying a precise and homogeneous threshold to identify intermediate cities: they vary in time and space (Manzagol 2003), and the demographic criterion is therefore merely indicative. Furthermore, the spatial references considered to determine the demographic threshold may vary. In some cases, researchers consider a central municipality or a morphological urban area only. In other cases, they consider a functional urban region or divisions based on the political-administrative framework (for instance on the NUTS typology).

Other authors have favoured a more qualitative approach. According to Carrière (2008: 20), the challenge is "to identify cities that play 
an intermediate role between cities with a high international visibility and all other levels of the spatial hierarchy". The quest for an intermediate urban level is close to a Christallerian vision of a territorial organisation based on central place theory. It is consistent with the aim for a balanced development of the European territory. This strategy of polycentric development is formalised in the European Spatial Development Perspectives and advocated by European institutions (European Commission 1999; ESPON 2005). Nevertheless, the polycentric approach is in itself poorly defined spatially, and this strategy can be described as a political consensus rather than a precondition for spatial development (Vandermotten et al. 2008).

More recently, the ESPON project called Second-Tier Cities and Territorial Development in Europe has identified secondary European cities as "those cities that are not capital cities and whose economic performance is significant enough to affect the potential performance of the national economy" (ESPON 2012: 3; Evans 2015: 163). However, this definition identifies Barcelona, Milan or Lyon as secondary cities. In our view, they cannot be regarded as such because they are part of the European network of major cities and, in some cases, they have a stronger socio-economic weight than their related national capitals.

For our analysis, we chose to define intermediate cities as important regional or national cities, small metropolises or large towns, sometimes with a transnational dimension. Although they are not the capital or the main metropolis of their country, their economic and demographic weight is significant in the conditions of the national economy. At an inter-urban scale, they are poorly or moderately connected to the network of capitals although they are major European cities. At the scale of their urban areas, they provide services, amenities, jobs and a privileged place for interactions and innovations.

\section{Territories of intermediate cities}

The spatial definition of urban territories is a classical pitfall of empirical analyses in urban geography. However, despite the different definitions of 'urban', cities can usually be defined in three approaches: first, as legal entities; secondly, as morphological areas; and thirdly, as functional units (Pumain et al. 1992; Rozenblat 2003; Paulet 2005).

The city as a political-legal-administrative entity is defined relative to the urban community and its modes of territorial appropriation. It refers, in the context of the modern state, to local administrations and their boundaries, i.e. communes, municipalities, districts, councils, and so on. The legal definition makes it easy to identify urban entities because their boundaries are officially recognised. For metropolises and intermediate cities, researchers generally distinguish a central political-administrative unit (city centre) from other constituent units: entities of the morphological urban area (an urban agglomeration) or entities of the functional urban area (an urban region).

The morphological area refers to an "urban coherence" (Pumain et al. 1992) related to the predominance of built-up areas. Urban agglomerations - also known as morphological units or urban units - can exceed political and administrative boundaries and their limits are identified taking into account built-up continuity on the basis of a 'tolerance threshold' between buildings (typically 200 metres).

An urban region refers to a functional city and its socio-economic dynamics. This is a territory that includes areas drawn by the influence of an urban centre. Urban regions are usually defined by their travel-to-work areas (TTWAs) and correspond to the daily-life area of the urban population. It is this approach that we chose to use in our analysis. Indeed, in this wide definition urban space is also an area of main urban challenges: suburbanisation, commuting, planning, economic growth, sustainable development, socio-spatial segregation, etc.

\section{Size of local governments in Europe}

In this chapter, we will see that territorial structures defined by national governments and the territorial reforms they pursue are of primary importance in explaining the internal organisation of European intermediate urban regions and, as a consequence, the need to develop forms of collaboration between local governments.

We identified the local level of political-administrative entities on the basis of national legislation and information available from European 
organisations (Table 1). It is on the basis of those entities that we decided to analyse how local governments were organised and how European intermediate urban regions were fragmented.

The local territorial organisation varies greatly within our study area. Some of the considered countries have adopted a uniform and one-tier structure of local units (e.g. Belgium, France, the Netherlands). By contrast, other have complex and heterogeneous structures of local units with one or two government levels (e.g. the United Kingdom). When the local organisation of a territory is based on two-tier governments, we give priority to the level with the widest competences on territorial issues. For the United Kingdom, we have therefore considered unitary authorities and upper principal authorities at the expense of lower entities in the two-tier system.

On the basis of national population data (Eurostat 2015) and national area data (Eurostat 2014, INSEE 2015), we calculated the average population and the average area of a local unit in each country (we did not consider overseas territories). The two fragmentation indicators show a wide variation between the European Union countries and the associated states (Fig. 1). The extreme values are, on the one hand, the Czech Republic (1,686 inhabitants; $\left.12.6 \mathrm{~km}^{2}\right)$ and Cyprus $\left(1,620\right.$ inhabitants; $\left.17.7 \mathrm{~km}^{2}\right)$ and, on the other hand, Ireland (149,222 inhabitants; $\left.2,251.5 \mathrm{~km}^{2}\right)$ and the United Kingdom (434,679 inhabitants; $\left.1,668.0 \mathrm{~km}^{2}\right)$. The averages of the 30 national indicators are 34,105 inhabitants and $385 \mathrm{~km}^{2}$.

This diversity reflects the heterogeneity of population geography in European countries, but also the long history of territorial appropriation by communities as well as the reconfiguration processes of local administrative units. Without doubt, the most significant trend in the recent decades has been the merging of local units experienced by many countries after the Second World War, for example Belgium in 1977 (from 2,359 to 596 municipalities), the Netherlands (from 647 municipalities in 1991 to 403 today), Denmark in 2007 (from 270 to 98 municipalities), Greece in 2011 (from 1,033 to 325 dimos), or Ireland in 2014 (from 114 to 31 local authorities). These mergers were simultaneous or spread over time, and national (e.g. in Belgium) or regional (e.g. in Germany). The convergence towards merging processes in all countries shows that the structural trend in Europe is to reduce the number of local political-administrative units. By contrast, creations or divisions remain marginal, with the noticeable exception of the de-merging of local politico-administrative units in some Central and Eastern European countries during the restoration of local self-government authorities after the 1989-1990 democratic breakthrough.

A hierarchical cluster analysis (Ward's method, the same weighting of variables, values reduced - centred) determines groups (aggregation

Table 1. Political-administrative local units in European countries and their national typologies, sources and reference dates.

\begin{tabular}{|l|l|r|l|c|}
\hline \multicolumn{1}{|c|}{ Country } & \multicolumn{1}{|c|}{ Local level } & Number & \multicolumn{1}{c|}{ Source } & Ref. date \\
\hline Austria & Gemeinde (Community) & 2100 & Statistik Austria & 29.10 .15 \\
& - Gemeinde & -1130 & & \\
& - Marktgemeinde & -769 & & \\
& - Stadtgemeinde & -186 & & \\
& - Statutarstadt & -15 & & 31.10 .15 \\
\hline Belgium & Commune (Community) & 589 & SPF Intérieur & 15.10 .15 \\
\hline Bulgaria & Obshtina (Community) & 265 & DG EC SA & 01.01 .15 \\
\hline Croatia & Opcina (Municipality) & 428 & CBS & \\
& Grad (City/Town) & 128 & & 01.01 .11 \\
\hline Cyprus & Koinotites (Community) & 484 & CCRE & 01.01 .10 \\
& Dimoi (Municipalities) & 6250 & CSU & 01.01 .15 \\
\hline Czech Republic & Obec (Municipalities) & 98 & DST & 01.01 .15 \\
\hline Denmark & Kommuner (Community) & 183 & Rahandusministerium \\
\hline Estonia & Vald (Rural municipality, parishes) & 30 & & 01.01 .15 \\
& Linn (Urban municipality) & 317 & Statistics Finland/Tilas- & 0 \\
\hline Finland & Kunta/Kommun (Municipality) & -107 & tokeskus & \\
& - Town/City & -210 & & \\
& - Municipality & & \\
\hline
\end{tabular}




\begin{tabular}{|c|c|c|c|c|}
\hline Country & Local level & Number & Source & Ref. date \\
\hline France & Commune (Community) & 36529 & INSEE & 01.01 .15 \\
\hline Germany & $\begin{array}{l}\text { Gemeinde (Community) } \\
\text { - Stadt } \\
\text { - Gemeinde }\end{array}$ & $\begin{array}{r}11162 \\
-2064 \\
-9097\end{array}$ & DESTATIS & 01.01 .14 \\
\hline Greece & Dimos (Municipality) & 325 & ELSTAT & 31.12 .14 \\
\hline Hungary & $\begin{array}{l}\text { Municipality (Telepules) } \\
\text { - Város (Town) } \\
\text { - Megyie Jogù Város (Town with county } \\
\text { rights) } \\
\text { - Nagyközsèg (Large Municipality) } \\
\text { - Közsèg (Municipality) }\end{array}$ & 3176 & KSH & 31.12.14 \\
\hline Ireland & $\begin{array}{l}\text { County } \\
\text { - County council } \\
\text { - City and County council } \\
\text { - City council } \\
\text { Divided in Municipal districts }\end{array}$ & $\begin{array}{r}31 \\
-26 \\
-2 \\
-3 \\
95\end{array}$ & Irish Gov & 01.01 .15 \\
\hline Italy & Comune (Community) & 8047 & ISTAT & 30.01 .15 \\
\hline Latvia & $\begin{array}{l}\text { Novads (Municipality) } \\
\text { - Novads (Municipality) } \\
\text { - Pilseta (Republic city) } \\
\text { Divided in Towns and Parishes }\end{array}$ & $\begin{array}{r}119 \\
-110 \\
-9\end{array}$ & Gov Latvia & 01.01 .15 \\
\hline Lithuania & $\begin{array}{l}\text { Savivaldybé (Municipalities) } \\
\text { - Rajono savivaldybe (district municipality) } \\
\text { - Miesto savivaldybe (City municipality) } \\
\text { - Savivaldybe (Municipality) }\end{array}$ & $\begin{array}{r}60 \\
-43 \\
-7 \\
-10\end{array}$ & $\begin{array}{l}\text { Gov Lithuania/EuroGeo- } \\
\text { graphics }\end{array}$ & 01.01 .15 \\
\hline Luxembourg & Commune (Community) & 105 & STATEC & 01.01 .15 \\
\hline Malta & Kunsill Lokali (Local council) & 68 & Gov Malta & 01.01 .15 \\
\hline Netherlands & Gemeente (Community) & 393 & CBS & 01.01 .15 \\
\hline Norway & Kommune (Municipality) & 428 & SSB & 01.01 .15 \\
\hline Poland & Gminy (Municipalities) & 2478 & GUS & 01.01 .15 \\
\hline Portugal & $\begin{array}{l}\text { Municipios (Municipality) } \\
\text { divided in Freguesias (Parishes) }\end{array}$ & $\begin{array}{r}278 \\
2882 \\
\end{array}$ & INE & 01.01 .14 \\
\hline Romania & $\begin{array}{l}\text { Total } \\
\text { - Comune (Municipality) } \\
\text { - Orase (City) } \\
\text { - Municipii (City by law) } \\
\text { - Sector (District Bucharest) } \\
\end{array}$ & $\begin{array}{r}3187 \\
-2861 \\
-217 \\
-103 \\
-6 \\
\end{array}$ & INSSE & 01.01 .14 \\
\hline Slovakia & Obec (Municipality) & 2927 & SOSR & 01.08 .14 \\
\hline Slovenia & Obcin (Municipality) & 212 & Statisticnic Urad RS & 07.01 .15 \\
\hline Spain & Municipe (Community) & 8120 & INE & 01.01 .15 \\
\hline Sweden & Kommun (Community) & 290 & SCB & 01.01 .15 \\
\hline Switzerland & Commune (Community) & 2324 & OFS & 01.01 .15 \\
\hline United Kingdom & $\begin{array}{l}\text { Principal Authority (England) } \\
\text { - Unitary District } \\
\text { - Unitary County } \\
\text { - Two-Tier District (non metropolitan } \\
\text { district) } \\
\text { - Two-Tier County (non metropolitan } \\
\text { county) } \\
\text { - Metropolitan District } \\
\text { - London Borough } \\
\text { Principal Authority (Wales) } \\
\text { - Unitary Authority } \\
\text { Principal Authority (Scotland) } \\
\text { - Unitary Local Authority } \\
\text { Principal Authority (Northern Ireland) } \\
\text { - District Council }\end{array}$ & $\begin{array}{r}324 \\
-49 \\
-6 \\
-201 \\
-27 \\
-36 \\
-32 \\
22 \\
-22 \\
32 \\
-32 \\
11 \\
-11 \\
\end{array}$ & $\begin{array}{l}\text { LGBCE } \\
\text { Welsh Government } \\
\text { Scottish Government }\end{array}$ & $\begin{array}{l}21 / 09 / 2015 \\
18 / 06 / 2015 \\
01 / 05 / 2015\end{array}$ \\
\hline
\end{tabular}




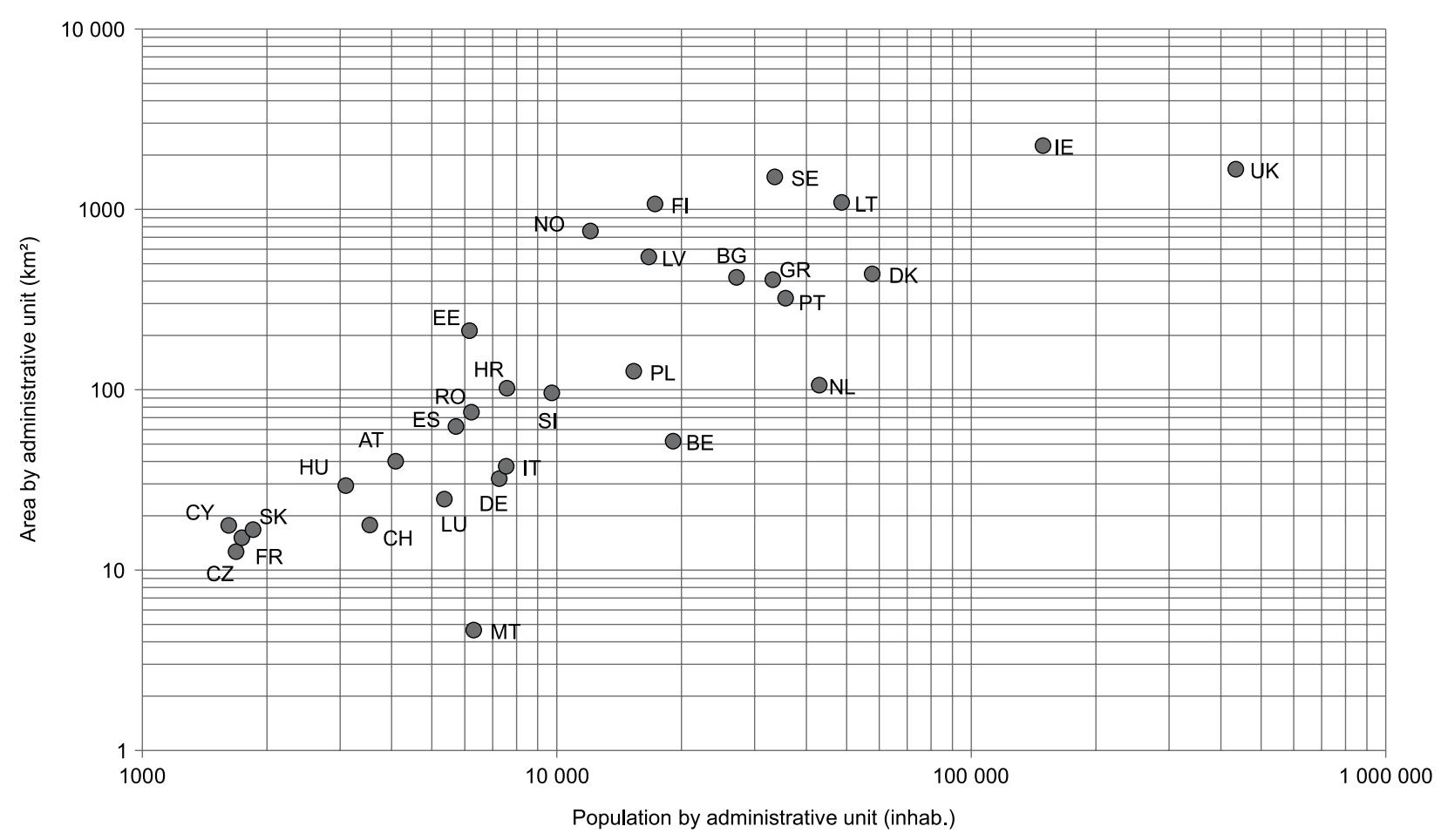

Fig. 1. Distribution of European countries by indicators of the average population and area (logarithm scale).

distance $>4$ ) and subgroups (aggregation distance $<4$ ) of countries:

- group 1: Ireland, the United Kingdom;

- group 2: Finland, Sweden, Lithuania;

- group 3: Latvia, Norway, Bulgaria, Greece, Portugal, Denmark, the Netherlands;

- sub-group 4a: Estonia, Poland, Belgium;

- sub-group 4b: Malta, Luxembourg, Italy, Germany, Spain, Romania, Slovenia, Croatia; and

- sub-group 4c: Austria, Hungary, Switzerland, Cyprus, France, Slovakia, the Czech Republic.

The numerous reforms of local collectivities in the United Kingdom (group 1), particularly reforms in the Thatcher era, have led to the establishment of very large and highly populated units. By contrast, most countries in the last group (4c) have experienced little change in the framework of local units. France is a good example here. Due to the resistance of local communities and elected representatives to changes, laws aiming to merge municipalities (e.g. the Marcellin Law, 1971) have had a very limited impact.

Notable in the other groups is the influence of national geographical features (particularly in the Scandinavian countries), as well as the influence of the extent and temporality of territorial reforms. Germany belongs to group $4 \mathrm{~b}$ although some of its Länder have undergone significant mergers. Some countries that have experienced recent mergers tend to be at the top of the ranking. The difference between old and recent mergers and the pursuance of the fusion process even in countries that previously experienced mergers support the hypothesis of a structural transformation of the local political-administrative level in favour of more populated and extensive entities. It therefore confirms the importance of this level of organisation.

\section{Fragmentation of local governments in European intermediate urban regions: development of the methodology}

The development of a methodology to analyse the fragmentation of European intermediate urban regions requires three specific tasks. The first is to delineate the borders of urban regions that may be considered intermediate ones. The second is to select intermediate urban regions, and the third is to identify the local political-administrative units composing them. These three tasks are described below. 


\section{Spatial delimitation of intermediate urban regions in Europe}

The objective of delineating European urban regions is common to many researchers and actors such as lobbyists, non-governmental actors, European, national and regional authorities, etc. They all use urban comparative analysis and ranking when they work on cohesion policies and territorial development strategies.

To accomplish our research tasks, we analysed and compared three approaches developed to delineate European urban regions: functional urban areas (FUAs) defined in the context of ESPON (ESPON 2011; Peeters 2011), large urban zones (LUZes) from Eurostat (Eurostat 2015; Dijkstra, Poelman 2012), and metropolitan regions, also from Eurostat (Eurostat 2015; Dijkstra 2009).

Figure 2 dealing with the case of the Belgian city of Liège shows that the three approaches give rather contrasting results in terms of delimitation. In this perspective, we can formulate the hypothesis that divergences between the three approaches are also sources of significant statistical divergences in fragmentation indicators. The three analysed approaches are characterised by features (Table 2) that help explaining differences between the delimitations and those in fragmentation indicators.

\section{Functional urban areas (FUAs) from ESPON}

The European Observation Network for Territorial Development and Cohesion (ESPON) has developed several research programmes to define European cities (urban regions) spatially in order to set up databases for comparative analyses.

In 2005, the first study of the potential for polycentric development in Europe identified 1,595 functional urban areas (FUAs) with more than 20,000 inhabitants (ESPON 2005). It was carried out in 27 EU countries as well as in Norway and Switzerland (Croatia was not considered at that time). It was based on various national methodologies aiming to delineate FUAs. As a consequence, despite the support of local experts, this research introduced a methodological bias due to the heterogeneity of national approaches in terms of both, conceptual approaches and data availability. This heterogeneity appeared to be particularly problematic for FUAs; a response to this criticism was given by the Study on urban functions (ESPON 2007) that sought to develop an integrated methodology.

This common methodology is based on the delimitation of morphological urban areas (MUAs) to identify the corresponding FUAs. MUAs were delimited for each FUA above 50,000 inhabitants identified by the ESPON 2005 study. For each of these regions, municipalities (the LAU2 level in European statistical nomenclature) with more than 650 inhabitants per $\mathrm{km}^{2}$ were selected and aggregated by removing enclaves or exclaves. On this basis, new boundaries of FUAs were then fixed by considering the travel-to-work areas (TTWAs) of the MUAs. This was done by considering all local units (LAU2) with at least $10 \%$ of the employed population commuting to MUAs. An outer ring of local units was also added and exclaves and enclaves were removed once again, so as to obtain spatially coherent FUAs.

The ESPON database was updated in the framework of the ESPON 2013 DB Project by Peeters (2011) on the basis of the following data:

- the spatial definition of local administrative units (LAU2) provided by Eurogeographics for 2008;

- the MUA population in 2001 as available in ESPON 1.4.3 research (ESPON 2007);

- the SIRE database from the European Commission (Europe Infra-Regional Information System) for the population of LAU2 entities (2001 and 2006); and

- national statistics regarding travel to work in 2001.

It is important to observe that TTWA data were missing at the local level for several countries (Poland, Romania, Latvia, Lithuania) and questionable for other ones (Hungary, Bulgaria and Slovenia; Peeters 2011).

While some data may seem relatively old, particularly those on travel to work (2001), the author argues that FUAs remain relatively stable over time because of the low commuting threshold adopted (a rate of 10\%) (Peeters 2011: 6). This threshold is indeed 5\% lower than the usually considered limit (e.g. Vandermotten 2003; Eurostat 2012). As a consequence, it tends to overestimate the TTWAs of the MUAs.

The MUAs and FUAs as defined by ESPON are proxies that we consider consistent with the objective of identifying European morphological 

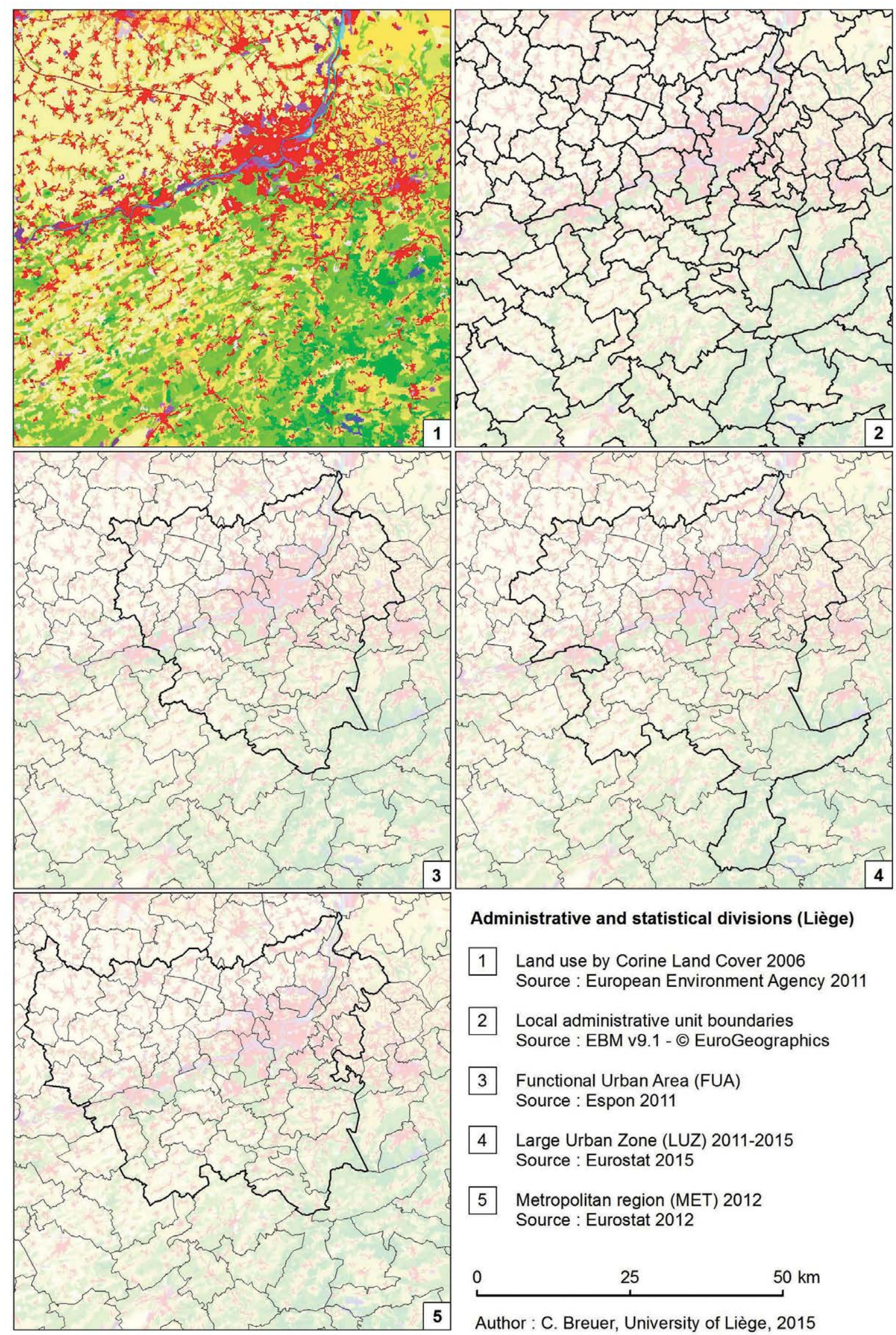

Administrative and statistical divisions (Liège)

1 Land use by Corine Land Cover 2006 Source : European Environment Agency 2011

2 Local administrative unit boundaries Source : EBM v9.1 - ( ) EuroGeographics

3 Functional Urban Area (FUA) Source : Espon 2011

4 Large Urban Zone (LUZ) 2011-2015 Source : Eurostat 2015

5 Metropolitan region (MET) 2012 Source : Eurostat 2012

0

25

$50 \mathrm{~km}$

Author: C. Breuer, University of Liège, 2015

Fig. 2. Urban statistical divisions in Liège, Belgium. 
Table 2. Main characteristics of urban databases at the European scale.

\begin{tabular}{|c|c|c|c|}
\hline Characteristics & $\begin{array}{l}\text { Functional Urban Area } \\
\text { (FUA) }\end{array}$ & $\begin{array}{c}\text { Large Urban Zone/ } \\
\text { Functional Area (LUZ) }\end{array}$ & Metropolitan region (MET) \\
\hline Author/provider & Espon & Eurostat & Eurostat \\
\hline Reference date & 2011 & 2011-2015 & 2011 \\
\hline Goal(s) & $\begin{array}{l}\text { Study of polycentricity and } \\
\text { urban functions in European } \\
\text { countries }\end{array}$ & $\begin{array}{l}\text { Statistical boundary for Eu- } \\
\text { ropean urban audit program } \\
\text { (Cities) }\end{array}$ & $\begin{array}{l}\text { Statistical proxy of urban } \\
\text { region on a NUTS } 3 \text { basis }\end{array}$ \\
\hline $\begin{array}{l}\text { Number of countries } \\
\text { with available data }\end{array}$ & 29 & 29 & 30 \\
\hline Strenghts & $\begin{array}{l}\text { Transnational delimitation } \\
\text { for urban regions, consistent } \\
\text { methodology on a morpho- } \\
\text { logical - functional basis }\end{array}$ & $\begin{array}{l}\text { Database update, number of } \\
\text { indicators, consistent meth- } \\
\text { odology on a morphological } \\
\text { - functional basis }\end{array}$ & $\begin{array}{l}\text { Database update, number of } \\
\text { indicators for economic top- } \\
\text { ics, link with upper Eurostat } \\
\text { statistical units (NUTS) }\end{array}$ \\
\hline Weaknesses & $\begin{array}{l}\text { Lack of commuting data for } \\
\text { some countries, database up- } \\
\text { date by aggregation of lower } \\
\text { statistical units }\end{array}$ & $\begin{array}{l}\text { Poor transnational delimi- } \\
\text { tation for urban regions, no } \\
\text { statistical comparison with } \\
\text { upper Eurostat statistical } \\
\text { units (NUTS) }\end{array}$ & $\begin{array}{l}\text { Not on a morphological - } \\
\text { functional basis, statistical } \\
\text { bias induced by NUTS size }\end{array}$ \\
\hline
\end{tabular}

agglomerations and urban regions. When transnational commuting data are available, FUAs adequately integrate transnational urban regions like Luxembourg and Geneva. Nevertheless, they suffer from the difficulty of updating demographic and economic statistics because MUAs and FUAs are not part of the statistical system of the European Commission. In concrete terms, data must be aggregated from the municipal level, and such an aggregation is difficult because data have to be collected from different national statistical institutions.

\section{Large urban zones (LUZes) from Eurostat}

In 1999 Eurostat established an urban audit (now called "Cities") to collect data on the state of European cities. This interest in urban statistics follows the growing interest of the European Commission in urban policy so as to achieve the aims of development, cohesion, innovation, competitiveness, and quality of life within the Union. Information is collected through national statistical institutes for 162 variables and 61 indicators (the 2011-2015 audit). The statistics are mainly collected at three levels: the intra-urban scale (sub-city districts), the morphological agglomeration (the core city or city), and the urban area (a large urban zone, a large urban area, or a functional urban area).

During the first waves of data collection, statistical divisions had no harmonised methodology within the member states. As a consequence, a strong statistical bias dramatically limited the international comparability of urban statistics. It therefore also limited the use of the database and, moreover, it lowered its credibility (Eurostat 2010, 2012).

In 2011, the European Commission and the Organisation for Economic Cooperation and Development (OECD) responded to this criticism by adopting a new harmonised methodology for identifying cities and their urban regions (Dijkstra et al. 2012). This work was completed for 29 countries (27 EU states as well as Norway and Switzerland), and it is now used to collect statistics in the framework of the Cities programme. The developed methodology differentiates between two areas of each urban region: a city and a larger urban zone:

1. A city (formerly known as a core city or city centre) is defined on the basis of a high-definition grid (a raster image) of the European population. This approach is based on a remote sensing analysis where the population density is inferred by land-use characteristics. All cells with more than 1,500 inhabitants per $\mathrm{km}^{2}$ are then selected and aggregated to contiguous cells. Enclaves and exclaves are again removed to smooth the delimited area. Entities with more than 50,000 inhabitants are retained as 'urban centres'. All local administrative units (LAU2) having at least $50 \%$ of their population in an urban centre are candidates to be part of the city. In the last step, national authorities ensure that the city is defined in relation 


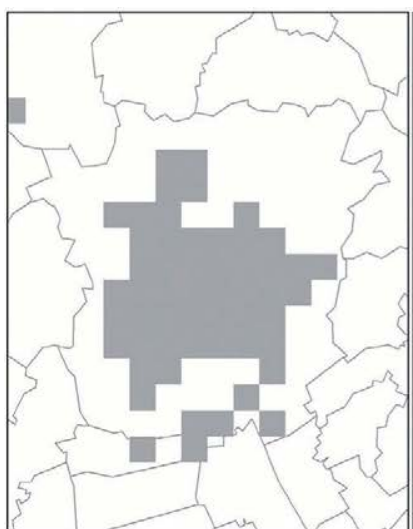

High density cell (>1500 inh. per sq.km.) Municipalities

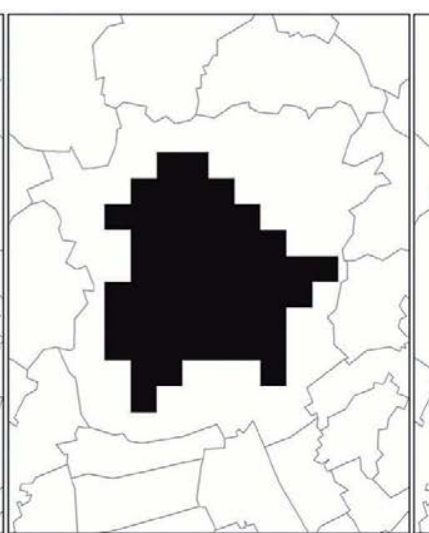

Urban Centre (Cluster of HD cells with population $>50.000$ )

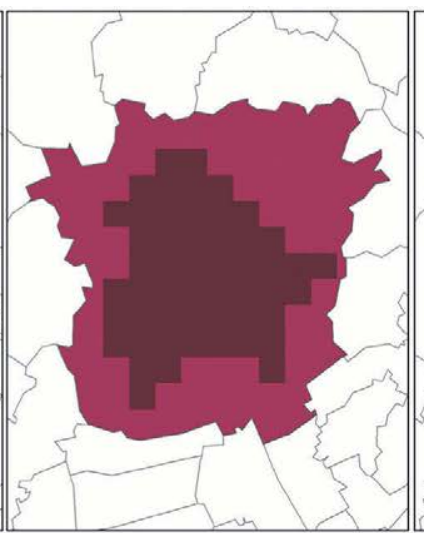

Commune $>50 \%$ of its population
in an urban centre

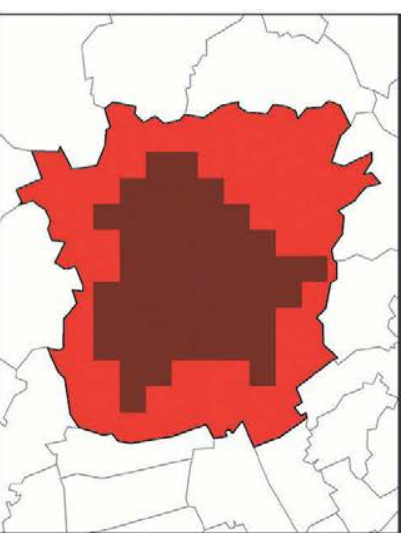

Urban Audit City

Fig. 3. Eurostat methodology for the delimitation of cities: high-density cells, urban centre, commune, and urban audit city (the city of Graz).

Source: Dijkstra et al. (2012: 2).

to an existing political level (inter-municipal or regional authorities, urban associations), that $50 \%$ of the population of this political level must be in the urban centre, and that $75 \%$ of the urban centre population lives in the city. Thus, the city identifies an area of high population density, which can be assumed to be densely built-up and close to the morphological agglomeration concept. In parallel, it is also connected with a local political level or an upper level of government. We consider that the link made with political boundaries introduces new comparability problems and a new bias in the identification of morphological urban agglomerations.
2. Larger urban zones (LUZes) are defined on the basis of commuting zones to cities (Fig. 4). The notion of a LUZ is therefore close to that of a functional urban region. Statistically, the municipalities considered are those where $15 \%$ of the working population travels to centres. Once again, enclaves and exclaves are removed. The commuting data come from the SIRE database of the European Commission for 2001 and 2006. However, some countries do not provide such data: Iceland, Lithuania, Malta and Romania. For those countries, previous LUZ delimitations were used. In Spain and Hungary, LUZes were revised on the basis of more recent TTWAs (the 2011 census).

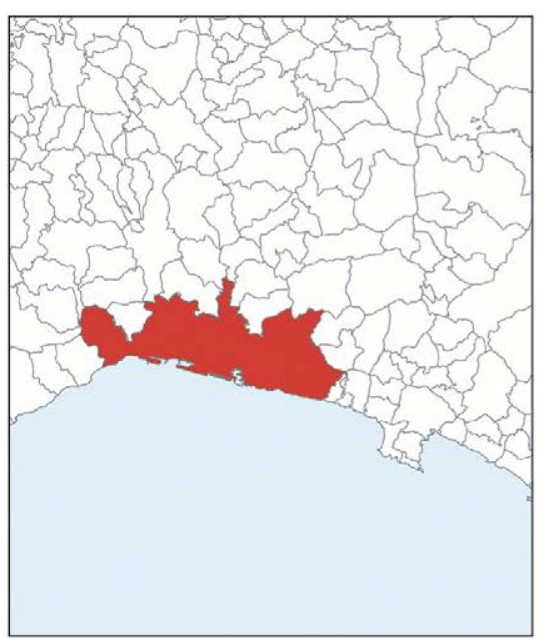

City Commune

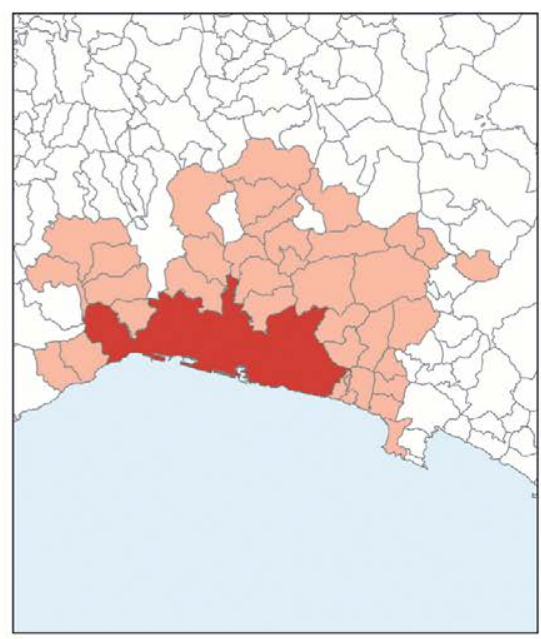
Commune with $>15 \%$ of its employed population
commuting to the city

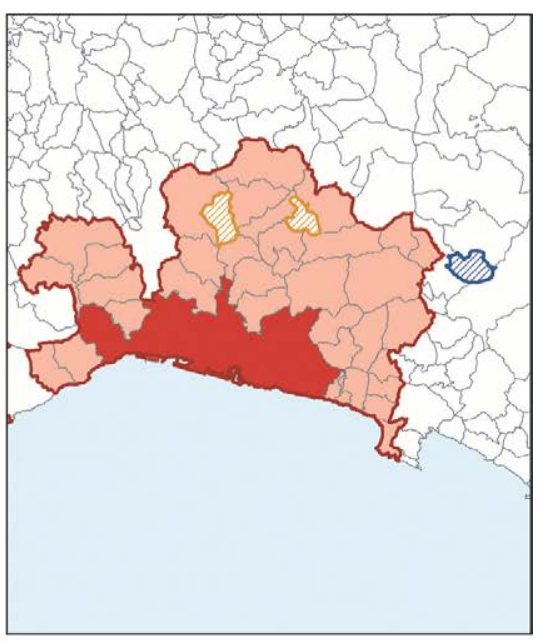

Larger Urban Zone Added enclave Removed exclav

Fig. 4. Eurostat commuting zone methodology. Source: Dijkstra et al. (2012: 3). 
In all, the general methodology developed by Eurostat is not much different from that used in the context of the ESPON programmes (Peeters 2011). However, we can note two main differences. The first concerns the population threshold taken into account in defining urban regions. In both cases, 50,000 is considered as the limit, but this limit is applied by Eurostat to the city level (therefore in relation to the notion of a morphological unit) and by Espon to the FUA level (therefore in relation to the notion of a functional unit). The second difference concerns the threshold used to apprehend commuting: $15 \%$ for the LUZes against $10 \%$ for the FUAs. Moreover, let us recall that the FUA methodology is also based on the addition of an outer ring beyond the $10 \%$ limit. As a consequence, FUAs are usually larger than their corresponding LUZes.

\section{Metropolitan regions from Eurostat (METs)}

NUTS 3 is the lowest level of the nomenclature of territorial units for statistics (NUTS). It is also the basis of the European regional statistical system. In this perspective, the work developed to define a LUZ was adapted to the NUTS 3. This led to the notion of metropolitan regions (METs) including NUTS 3 regions where more than 50\% of the population belongs to a LUZ, which implies that some METs are made of several NUTS 3 regions.

The advantage of the adaptation of the LUZ delimitation to the NUTS 3 framework is that the data can be easily updated by Eurostat (annually for most of the data). However, since NUTS 3 entities are purely political and administrative ones, this adaptation causes a strong delimitation bias.

\section{Selecting intermediate cities}

Now that we have presented the three databases available at the European level to delimit urban regions, we have to select our population of European intermediate urban regions. The selection was conducted on the basis of Eurostat's LUZ approach. This choice is justified by three main reasons. The first is practical and refers to the possibility of mobilising the wealth of information of the Cities programme (as a reminder: 162 variables and 61 indicators for the 2011-2015 audit). The second reason is that the LUZ approach is based on more complete and up-to-date data concerning TTWA delimitation. Finally, the third reason is the fact that the delimitation of FUAs probably tends to overestimate the areas of many urban regions. As mentioned above, this threat is related to the methodology used to delimit TTWAs (the low threshold of $10 \%$ plus the inclusion of an outer ring).

The database of the Cities programme identifies 948 cities in the 28 states of the European Union and its four partner countries (Switzerland, Norway, Iceland and Turkey). Out of the 948 cities, only 596 have available statistical data in the framework of the Cities 2011-2015 programme. These 596 LUZes represent 306,563,000 inhabitants, or $59.1 \%$ of the population of the countries concerned. This percentage rises to $59.5 \%$ for the EU countries. In other words, $59.5 \%$ of the EU population is included in the Cities programme.

We observe strong national disparities in the population size of the LUZes. For 21 countries with more than 5 LUZes, national averages vary from 0.228 (SK) to 1.110 million (UK) inhabitants by LUZ. The median indicator, which probably gives a more representative view due to the macrocephaly of some national urban networks, varies in a more contained range, from 0.112 (BG) to 0.522 (UK) million inhabitants. At the scale of the continent, the median is 0.241 million inhabitants.

The distribution of LUZes into quartiles also gives interesting information (Fig. 5). In our sample, $25 \%$ of the population lives in a LUZ with more than 2,817,000 inhabitants, $50 \%$ in a LUZ with more than 1 million inhabitants, and $75 \%$ in a LUZ with more than 368,000 inhabitants. The next $25 \%$ of our sample concerns small and medium-sized towns. Compared with the entire EU (505 million inhabitants), 29\% of the European population lives in a LUZ with more than 1 million inhabitants and $15 \%$ in a LUZ with between 368,000 and 1 million inhabitants.

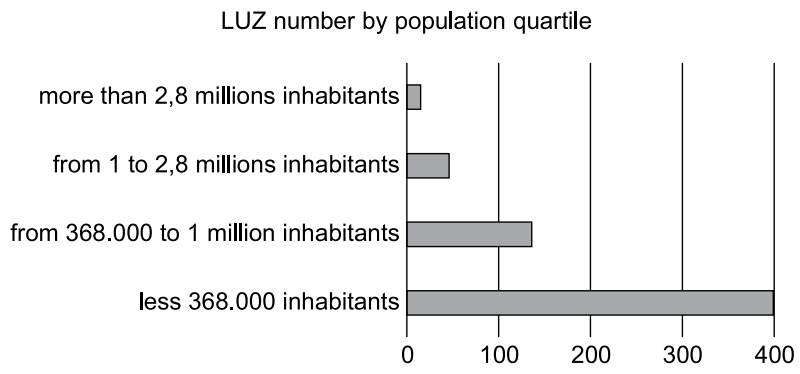

Fig. 5. LUZ number by population quartile. 
The following criteria were used to select our intermediate cities out of the set of 596 LUZes:

1. On the basis of the literature (see chapter 2 above), we used the following demographic thresholds: a LUZ must have a population of between 300,000 and 1.2 million. 190 LUZes meet this condition.

2. A LUZ must have an equivalent metropolitan urban region (MET). This is the case for only 182 LUZes because some of them have been integrated into polycentric METs (like the LUZ of Metz, which has been incorporated into the MET of Nancy).

3. Urban regions cannot be capitals of their countries. Indeed, capitals have long been run by specific political-administrative structures at the urban-region scale. As a consequence, they are not part of the same governance dynamic as intermediate cities. The sample is thus reduced to 176 LUZes.

4. Urban regions should be ranked in the French DATAR typology of European cities and in the typology from the Second State of European Cities Report (RWI). This criterion is useful for a further analysis of the link between city profiles and indicators of fragmentation in urban regions.

The French typology is a continuation of a research conducted in 1989 under the direction of Roger Brunet on behalf of the French Interministerial Delegation for Regional Planning and Regional Development (DATAR). This study was updated and supplemented in 2003 (Rozenblat et al. 2003) and in 2012 (Halbert et al. 2012). The second typology was produced on the basis of data from the urban audit of the European Commission. The two reports on the state of European cities (European Commission 2007; RWI 2010) highlight lessons from these data. The 2010 report gives an interesting division of cities into European city types.

Based on this last stage of selection, our sample includes 119 LUZes which represent 70,100,763 inhabitants (LUZ data from 2011-2015, depending on the country). The equivalent METs represent a significantly larger population, 97,257,857 (MET data for 2014).

\section{Indicators of local government fragmentation in urban regions}

Two indicators were used to analyse the political-administrative fragmentation of the 119 European urban regions considered (FUAs, LUZes and METs). The first was the average population by local administrative entity in an urban region. It is given by dividing the population of the LUZes, FUAs and METs by the number of local political-administrative entities in the corresponding area. This population-based fragmentation indicator reveals local political and administrative divisions of urban regions and potential structural constraints of coordination for local public actors.

The second indicator was the average area $\left(\mathrm{km}^{2}\right)$ by administrative unit in an urban region. It is given by dividing the area of the LUZes, FUAs and METs by the number of local political-administrative entities. This fragmentation indicator also provides information about political and administrative divisions.

Local political-administrative entities were identified from the geographical EuroBoundaryMap version 9.1 of the EuroGeographics Association containing administrative divisions in Europe as available on 1 January 2014 and delivered in March 2015. For comparative purposes, we also considered the number of entities on 1 January 2007 (EuroBoundaryMap v. 2.0, 2008). It appeared that the differences between the two periods were too small to provide useful information.

\section{Validation of the method and a preliminary analysis of the fragmentation of intermediate urban regions}

On the basis of the developed methodology, we now propose different data analyses to validate our approach. First, we compare indicators obtained from the three statistical divisions (FUAs, LUZes, METs). We then make a descriptive statistical analysis of our database and a classification of urban regions according to their fragmentation indicators. 


\section{Comparison of fragmentation indicators according to FUAs, LUZes and METs}

Table 3 summarises some key data concerning the LUZes, METs and FUAs. It provides information on fragmentation indices and the average population and area in the three approaches.

For the 119 urban regions considered, the average population by local administrative entity is 42,224 for a MET, 47,367 for a FUA and 50,289 for a LUZ. As to the average area, the indicator varies from $118 \mathrm{~km}^{2}$ (FUA) to $164 \mathrm{~km}^{2}$ (MET, $+38 \%$ ) per local unit. Since our sample includes the vast majority of European urban regions with between 300,000 and 1,200,000 inhabitants, we think that these differences are significant and that the methodological differences between the three forms of delimitation can lead to a severe bias in analyses of the fragmentation of intermediate urban regions.

Another result drawn from Table 3 is the confirmation that the use of the NUTS 3 framework is not relevant in an analysis of the fragmentation of European intermediate urban regions. Indeed, compared with both LUZes and FUAs, METs occupy much larger territories and they are also significantly more populated. This can be explained by the fact that MET territories include localities situated beyond the TTWAs of intermediate cities. Concerning the inadequacy of the NUTS 3 framework for an analysis of intermediate urban regions, let us also recall that some NUTS 3 regions include several LUZes as, for instance, in the case of Nancy where the MET contains the Metz urban region (the MET is here the Moselle Department, one French NUTS 3 unit).

As to the fragmentation indices, we see in Table 3 that the MET index is high for the area $\left(164 \mathrm{~km}^{2}\right)$ and low for the population $(42,224$ inhabitants). This situation illustrates the fact that a MET contains remote rural areas where local authorities combine usually large areas with small populations.

Table 3 also shows that the fragmentation indices for FUAs and LUZes are similar for both, the population index and the area index. This presumably reflects the similar methodologies used to delineate FUAs and LUZes. Correlations and distributions of statistics between FUAs and LUZes confirm this analysis. For instance, the LUZ and FUA population indices are significantly correlated $\left(R^{2}=0.5055\right)$. Moreover, when we exclude Hungarian, Bulgarian, Polish, Lithuanian, Slovenian and Romanian urban regions where proxies were used due to the lack of TTWA data, the correlation rises dramatically $\left(R^{2}=0.8356\right)$.

As a consequence, we conclude that while METs are proxies of European urban regions, their delimitation methodology using inherited boundaries (NUTS 3) is a significant bias when analysing fragmentation indicators. In addition, FUAs are biased by the lack of commuting data for many countries and the low threshold used for aggregating local units (10\%). For both FUAs and METs, the methodologies used lead to the inclusion of some rural and peripheral areas weakly linked with urban centres. Since this strongly influences fragmentation indicators, we rejected FUA and MET areas and only kept LUZ areas as defined by Eurostat in the audit Cities programme for the reference years 2011-2015. This methodology from Eurostat seems to be a major step in the research on European cities, but the situation is not perfect because of a lack of certain commuting data and a limited cross-border dimension.

\section{Preliminary analysis of the fragmentation of European intermediate urban regions}

The distribution of indicators in our sample shows a strong asymmetry towards low values.

Table 3. Descriptive statistics of fragmentation in LUZes, METs and FUAs.

\begin{tabular}{|l|c|c|c|c|c|c|}
\hline & & & \multicolumn{4}{|c|}{ Fragmentation indicators } \\
\hline \multicolumn{1}{|c|}{ Indicator } & $\mathrm{N}$ & Average & Average & Minimum & Maximum & Standard D. \\
\hline Population (LUZ) / inhab. & 119 & 589.082 & 50289 & 1142 & 390900 & 74784 \\
\hline Population (MET) / inhab. & 119 & 817.293 & 4222 & 750 & 561947 & 88118 \\
\hline Population (FUA) / inhab. & 119 & 617.271 & 47367 & 1089 & 315775 & 69550 \\
\hline Area (LUZ) / km² & 119 & 1.901 & 131 & 5 & 1634 & 231 \\
\hline Area (MET) / km & 119 & 4.875 & 163 & 6 & 4084 & 415 \\
\hline Area (FUA) $/ \mathrm{km}^{2}$ & 119 & 2.238 & 118 & 6 & 1577 & 189 \\
\hline
\end{tabular}


This means that the majority of urban areas are highly fragmented in terms of both, area and population (Figs 6, 7).

This distribution is especially dominated by French and most German urban regions which, because of their number, have a strong influence on the statistical distribution in the sample.

On the basis of a logarithmic representation (Fig. 8), the distribution seems closer to a normal curve. The correlation between the two indicators is medium $\left(R^{2}=0.42\right)$ and reveals the diversity of European regional contexts, in particular the heterogeneity of population geography.

The cartography of those indicators shows the huge diversity of fragmentation indicators within Europe (Fig. 9). The spatial distribution of the indicators shows a strong influence of national contexts, e.g. French and Swiss urban regions are in the same category, Irish and English ones are

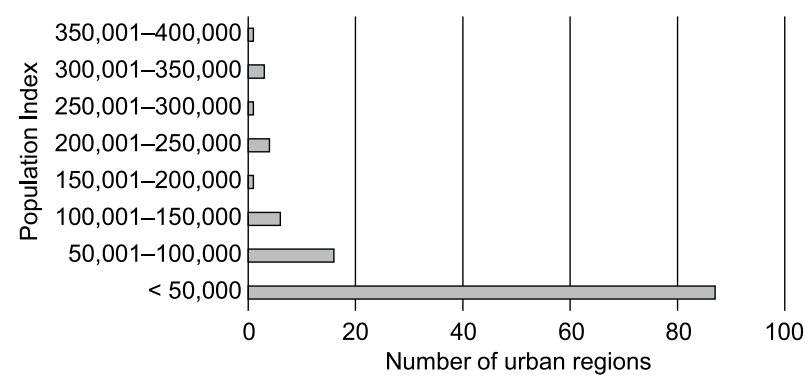

Fig. 6. Distribution of the population index. at the top of the ranking, etc. Nevertheless, some countries have a more contrasted distribution of indicators, e.g. Spain or Germany.

A hierarchical cluster analysis based on two indicators reduced/ centred by Ward's method (minimisation of intra-group variance and maximisation of inter-group variance; Fig. 10) demonstrates the predominance of national contexts as the main factor explaining variations in fragmentation among urban regions.

Six groups can be identified. Group 1 ( 9 urban regions) stands out for its low fragmentation both in terms of population and area (Leeds, Bristol, Sheffield, Bielefeld, Cork, etc.). Groups 2 (8 urban regions), 3 (16 regions) and 4 (7 regions) have a low population fragmentation indicator (e.g. Utrecht, Enschede, Odense), a high area indicator (Bergen, Malmö), or both (Belfast, Poznań, etc.). Group 5 includes 44 urban regions, the majority

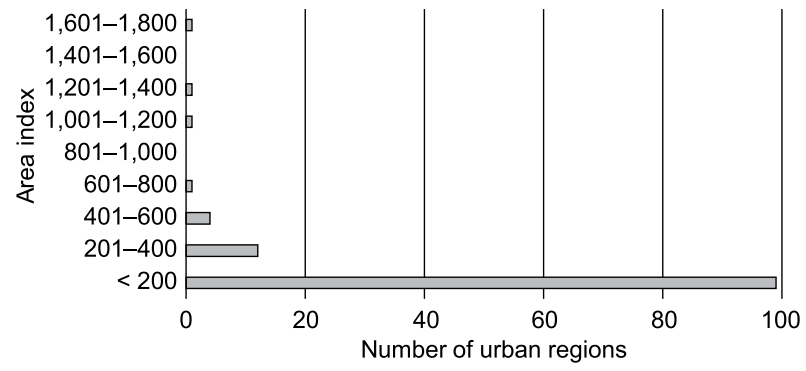

Fig. 7. Distribution of the area index.

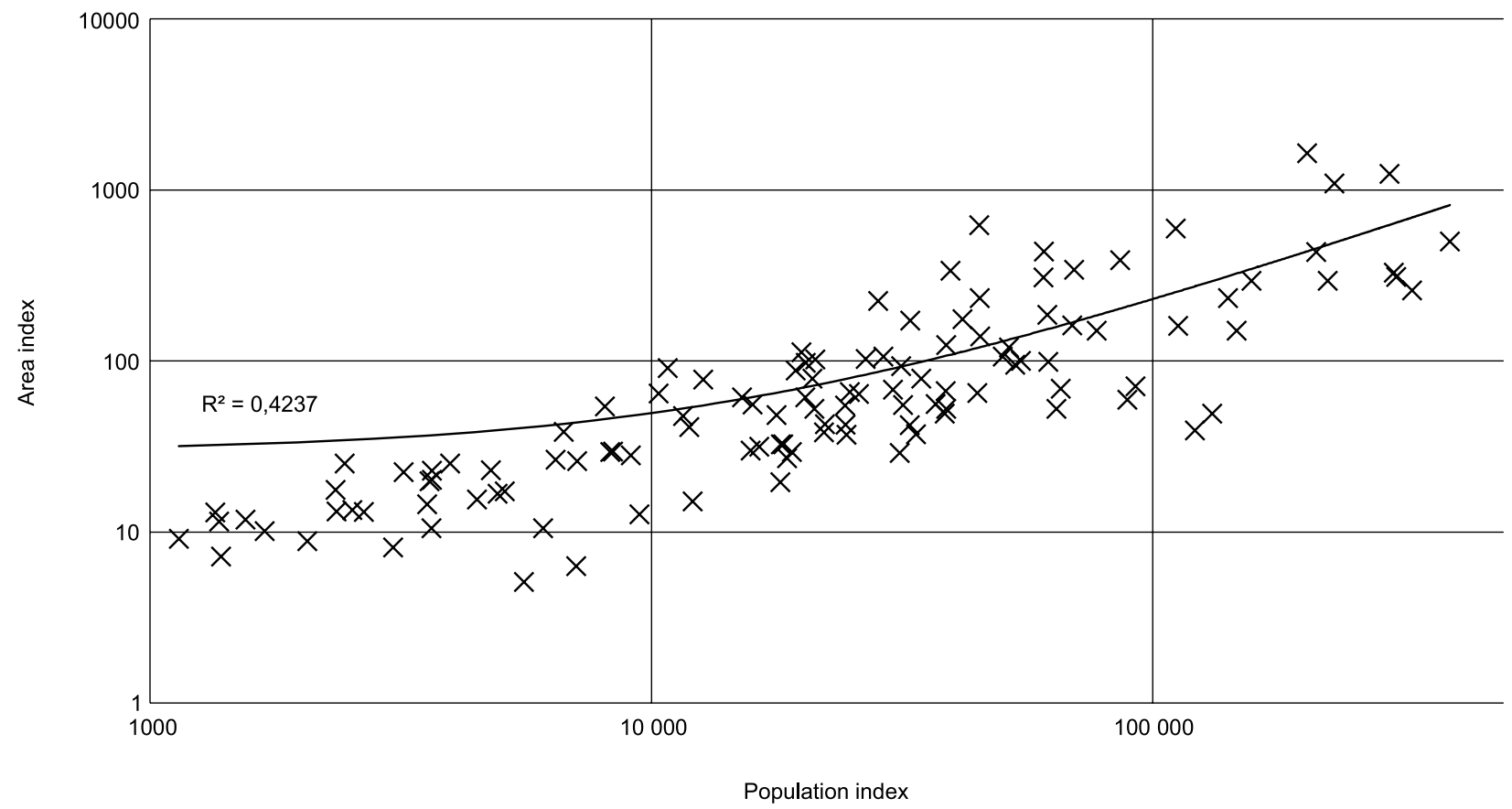

Fig. 8. Distribution of 119 urban areas (LUZes). 


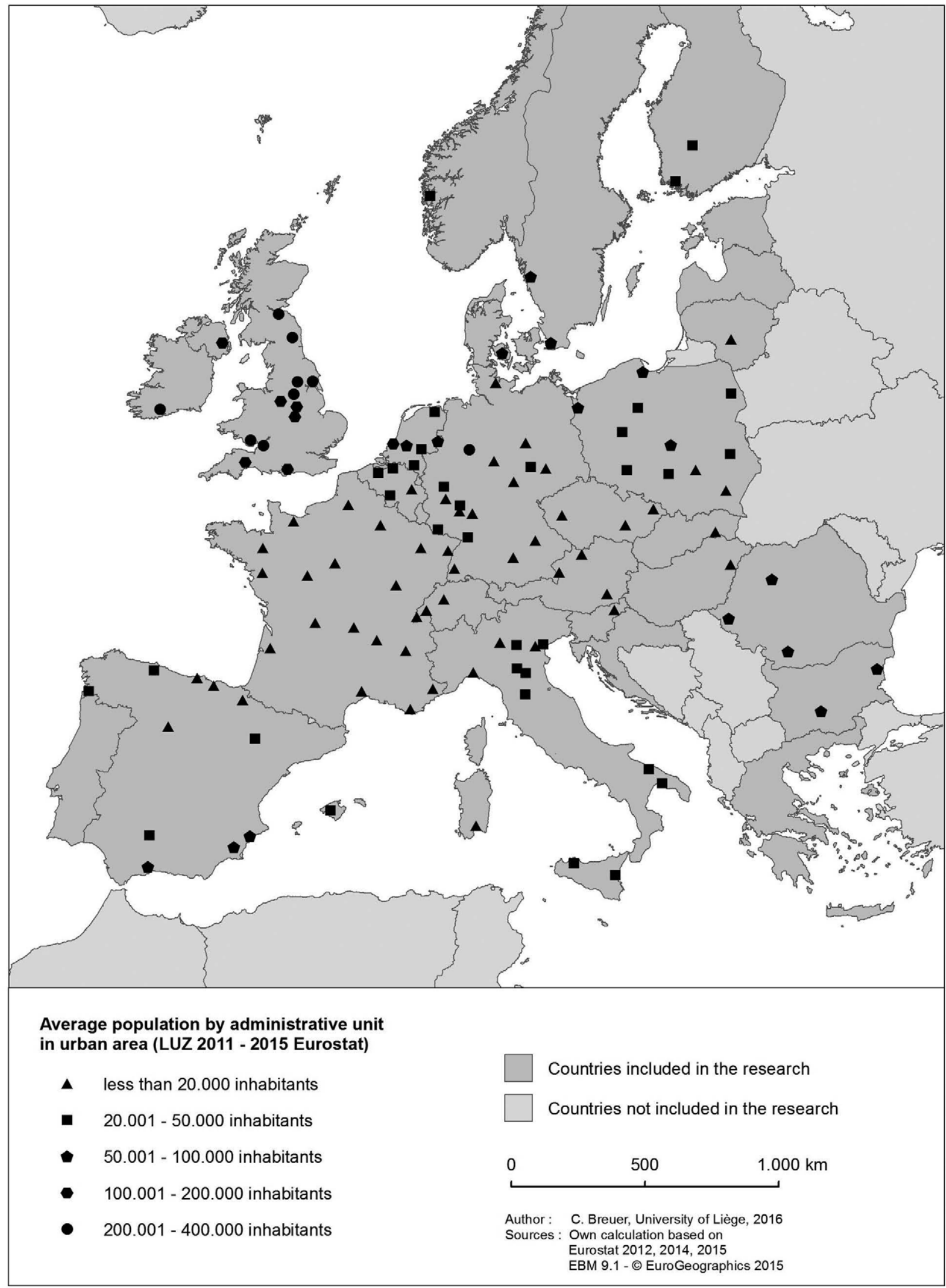

Fig. 9. Map of an average population by local unit in 119 intermediate European urban regions. 


$$
4
$$


Table 4 . Indicators by country.

\begin{tabular}{|c|c|c|c|c|c|}
\hline \multirow{2}{*}{$\begin{array}{l}119 \text { LUZ } \\
\text { Country }\end{array}$} & \multicolumn{5}{|c|}{ Index averages by country } \\
\hline & LUZ Nb. & Pop. Index & Ecart-type & Area Index & Ecart-type \\
\hline UK & 13 & $212,377.95$ & $89,169.60$ & 436.13 & 355.79 \\
\hline IE & 1 & $202,972.00$ & & $1,634.01$ & \\
\hline SE & 2 & $73,828.60$ & $17,333.30$ & 286.03 & 142.49 \\
\hline $\mathrm{RO}$ & 3 & $72,142.15$ & $14,725.78$ & 75.61 & 20.48 \\
\hline BG & 2 & $65,079.36$ & $6,456.08$ & 324.00 & 22.49 \\
\hline DK & 1 & $60,709.00$ & & 435.90 & \\
\hline NL & 6 & $56,340.54$ & $34,346.16$ & 70.57 & 27.76 \\
\hline NO & 1 & $39,533.80$ & & 335.74 & \\
\hline PL & 11 & $37,699.85$ & $16,683.59$ & 100.77 & 31.13 \\
\hline ES & 12 & $36,783.06$ & $25,596.43$ & 85.22 & 58.43 \\
\hline FI & 2 & $36,708.84$ & $11,845.86$ & 422.29 & 279.4 \\
\hline $\mathrm{DE}$ & 17 & $33,151.62$ & $76,995.71$ & 55.91 & 57.76 \\
\hline IT & 13 & $26,395.85$ & $8,798.18$ & 44.74 & 18.38 \\
\hline $\mathrm{BE}$ & 4 & $24,720.66$ & $7,090.34$ & 41.48 & 9.99 \\
\hline HU & 1 & $12,693.54$ & & 77.59 & \\
\hline LT & 1 & $11,567.85$ & & 47.67 & \\
\hline SI & 1 & $8,077.98$ & & 54.25 & \\
\hline $\mathrm{CH}$ & 3 & $7,376.55$ & $1,970.32$ & 8.03 & 4.09 \\
\hline AT & 3 & $4,253.29$ & $2,066.11$ & 23.06 & 4.80 \\
\hline FR & 18 & $4,143.33$ & $3,501.27$ & 17.70 & 7.35 \\
\hline $\mathrm{CZ}$ & 3 & $2,790.64$ & $1,892.06$ & 12.36 & 4.01 \\
\hline SK & 1 & 2,667.95 & & 13.06 & \\
\hline
\end{tabular}

of which have already experienced a territorial reform or a medium-scale merger of local authorities. It notably includes Belgian (Antwerp, Liège, Charleroi), Dutch (Eindhoven, Groningen), German (Leipzig, Magdeburg, Wiesbaden) and Spanish cities (Valladolid, Vigo). Group 6 brings together urban regions that are highly fragmented. They are in countries that have experienced very little change in their local frameworks: all French, Austrian and Czech urban regions as well as some Italian and German cities. The federal specificity of Germany and regional mergers explain the scattered distribution of German urban regions in several groups. The observed national averages reflect this variability and confirm a major influence of the national contexts.

Our data analyses also sought to explain the fragmentation indices on the basis of socio-economic criteria such as the size or the economic profiles of the urban regions. At this stage, due to the asymmetrical distribution of the indicators, the analyses could not go any further than to confirm the strong influence of the national contexts; however, the development of inferential statistical modelling probably offers elements of a solution.

\section{Conclusions}

To use the catchphrase employed by Le Galès (1995), urban governance has not replaced urban governments. Although they have been strongly transformed by international competition, by the privatisation of public services, and by the rise of private actors and interest groups in the management of cities, urban governments remain key - if not central - actors in urban governance. Intermediate cities are also affected by these structural mutations. However, few systematic and empirical studies have been conducted to characterise the context of their urban governance at the European scale. It is in this perspective that we developed a European exploratory methodology to assess local authorities of intermediate urban regions. This database is focused on two fragmentation indicators: population by administrative local unit and area by administrative unit.

Our methodological reflection integrated a comparison of three approaches to delineate urban regions (LUZes from Eurostat, METs from Eurostat, and FUAs from ESPON). This led to the conclusion that the LUZ methodology (reference years 2011-2015) was more adequate to the main 
objective of our research focused on urban governance. This methodology is closer to the classical definition of an urban region and integrates fewer purely rural areas than the MET and FUA approaches.

The institutional fragmentation values of urban regions highlight the predominance of national contexts in accounting for variations in the local political-administrative framework. Indeed, our database and descriptive statistical analysis indicate that urban regions from the same country share close fragmentation indicators, with the exception of urban regions in federal or highly decentralised states where fragmentation values can vary greatly from one city to another.

Thus far, our approach allowed us to create fragmentation typologies and groups. This information facilitates a benchmarking analysis at a European scale and the understanding of the context of urban collective dynamics across urban regions. Although the indicators have a high spatial dependence and an asymmetric distribution, inferential statistical analysis is an interesting perspective in which to test, on the basis of related literature, various hypotheses about the link between city profiles and the fragmentation of their urban regions. Another perspective is to expand our database with indicators reflecting the urban population distribution in urban areas. The complementarity of such indicators will help to refine our typology, but it depends on the availability of local demographic data.

In the long term, our methodology is reproducible and based on stable data updated regularly, both by Eurostat and institutional data providers. These features allow us to envisage making a diachronic analysis to refute or confirm the continuation of scale reconfigurations in European intermediate urban regions.

\section{References}

Antier G., 2005. Les stratégies des grandes métropoles. Enjeux, pouvoirs et aménagement. Armand Colin, Paris.

Benko G., Bouinot J., 2003. Compétitivité et promotion des villes moyennes. In: Villes moyennes et mondialisation. Renouvellement de l'analyse et des stratégies. Éditions trames, Université de Montréal, Montréal: 190-199.

Bevir M. (ed.), 2011. The SAGE Handbook of Governance. SAGE, London.

Boino P., Desjardins X., 2012. Intercommunalité: politique et territoire. La Documentation Française, Paris.
Brenner N., 1999. Globalisation as reterritorialisation: The re-scaling of urban governance in the European Union. Urban Studies 36(3): 431-451.

Brunet R., 1989. Les villes "européennes". La Documentation Française, Paris.

Brunet R., 1997. Territoires de France et d'Europe: raisons de géographie. Belin, Paris.

Budde R., Ehlert C., Neumann U., Grabow B., HollbachGrömig B., Seidel-Schulze A., Trofin L., Bergs R., 2010. Second State of European Cities Report. Rheinisch-Westfälisches Institut für Wirtschaftsforschung.

Carrière J.-P., 2008. Les villes intermédiaires européennes et l'Europe polycentrique? Réalités industrielles (1): 18-25.

Castells M., 1996. The rise of the network society: The Information Age: Economy, society and culture. Blackwell, Oxford.

Cattan N., Pumain D., Rozenblat C., Saint-Julien T., 1999. Le système des villes européennes. Anthropos-Economica, Paris.

Cornett P., 2014. A new regional balance: Challenges and opportunities for intermediate city regions. Paper presented at the 54th Congress of the European Regional Science Association, Saint Petersburg, Russia.

David Q., Peeters D., Van Hamme G., Vandermotten C., 2013. Is bigger better? Economic performances of European cities, 1960-1990. Cities 35: 237-254.

Dijkstra L., 2009. Regional focus. Metropolitan regions in the EU. European Commission, Brussels, 01/2009, Regional Policy.

Dijkstra L., Poelman H., 2012. Cities in Europe. The new OECDEC definition. Regional and Urban Policy, Brussels.

Dumont G.-F., 2012. Diagnostic et gouvernance des territoires. Concepts, méthode, application. Armand Colin, Paris.

ESPON, 2005. ESPON project 1.1.1. Potentials for polycentric development in Europe. ESPON Monitoring Committee, Luxembourg.

ESPON, 2007. ESPON project 1.4.3. Study on urban functions. ESPON Monitoring Committee, Luxembourg.

ESPON, 2012. SGPTD - Second Tier Cities and Territorial Development in Europe: Performance, Policies and Prospects. ESPON \& European Institute of Urban Affairs, Luxembourg.

European Commission, 2007. State of European Cities report. Adding value to the European Urban Audit. Brussels.

European Commission, 2009. Schéma de développement de l'espace communautaire. Vers un développement spatial équilibré et durable du territoire de l'Union européenne. Bruxelles.

European Commission, 2011. Cities of tomorrow. Challenges, visions, ways forward. European Commission, Directorate General for Regional Policy, Brussels.

Eurostat, 2005. European regional and urban statistics. Reference guide. European Communities, Luxembourg.

Eurostat, 2010. European regional and urban statistics. Reference guide. European Commission, Brussels.

Eurostat, 2012. Methodological manual on city statistics. European Commission, Brussels.

Eurostat, 2014. Eurostat regional yearbook 2014. Publications Office of the European Union, Luxembourg.

Eurostat, 2015. Eurostat regional yearbook 2015. Publications Office of the European Union, Luxembourg.

Evans R., 2015. Harnessing the economic potential of 'second-tier' European cities: lessons from four different state/urban systems. Environment and Planning C: Government and Policy 33: 163-183.

Giffinger R., Fertner C., Kramar H., Kalasek R., Pichler-Milanovic N., Meijers E., 2007. Smart cities - Ranking of European medium-sized cities. Vienna University of Technology. 
Gouvernement wallon, 2014. Déclaration de politique régionale 2014-2019. Namur.

Halbert L., Cicille P., Rozenblat C., 2012. Quelles métropoles en Europe. Des villes en réseau. La Documentation Française, Paris, Datar.

Hamza C., Frangenheim A., Charles D., Miller S., 2014. The role of cities in cohesion policy 2014-2020. European Parliament, Brussels.

Le Galès P., 1995. Du gouvernement des villes - la gouvernance urbaine. Revue française de science politique 45(1): 57-95.

Le Galès P., 2011. Le retour des villes européennes. Les Presses de Sciences, Paris.

Manzagol C., Charbonneau F., Lewis P., 2003. Villes moyennes et mondialisation: éléments de problématique. Villes moyennes et mondialisation. Renouvellement de l'analyse et des stratégies. Éditions trames, Université de Montréal, Montréal: 11-17.

Parkinson M., 2001. Key challenges for European cities: Achieving competitiveness, cohesion and sustainability. Area 33 (1): 78-80.

Pasquier R., Simoulin V., Weisbein J., 2013. La gouvernance territoriale. Pratiques, discours et théories. Librairie Générale de Droit et de Jurisprudence, Paris.

Paulet J.-P., 2005. Géographie urbaine. Armand Colin, Paris.

Peeters D., 2011. ESPON Database 2013 Project. The functional urban areas database: technical report. ESPON, Brussels.

Pumain D., Saint-Julien T., Cattan N., Rozenblat C., 1992. Le concept statistique de la ville en Europe. Office des publica- tions officielles des Communautés européennes, Luxembourg.

Rhodes R.A.W, 1996. The new governance: Governing without government. Political Studies XLIV: 652-667.

Rondinelli D.A., 1983. Dynamics of growth of secondary cities in developing countries. Geographical Review 73(1): $42-57$.

Rozenblat C., Cicille P., 2003. Les villes européennes. Analyse comparative. La Documentation Française, Paris.

Saint-Julien T., 2003. Les villes moyennes en Europe, contextes et défis. Villes moyennes et mondialisation. Renouvellement de l'analyse et des stratégie. Éditions trames, Université de Montréal, Montréal: 20-29.

Sassen S., 2001. The global city: New York, London, Tokyo. Princeton University Press, Princeton.

Schmidheiny K., Suedekum J., 2015. The pan-European population distribution across consistently defined functional urban areas. Economics Letters 133: 10-13.

Scott A.J., 2001. Globalization and the rise of city-regions. European Planning Studies 9(7): 813-826.

Sharpe L.J. (ed.), 1995. The government of world cities. The future of the metro model. John Wiley \& Sons, Chichester.

Turok I., Mykhnenko V., 2007. The trajectories of European cities 1960-2005. Cities 24(3): 165-182.

Vandermotten C., Halbert L., Roelandts M., Cornut P., 2003. European planning. Planning and the polycentric consensus: Wishful thinking? Regional Studies 42(8): 12051217. 